Anna Kienig

Uniwersytet w Biatymstoku

\title{
Modern Technology as the New Context of Child Development: Opportunities and Threats
}

The use of new information and communications technology (ICT) by young children is a source of controversy in many countries. It is extremely important to understand the impact of new digital devices (i.e., tablets) on child development. This article explores the occurrence of ICT in the context of child development, learning, and socialization. Specifically, this article focuses on technologies used in early childhood education, including how these new technologies are defined, in what ways they shape childhood (opportunities and threats), their role and potential in early childhood education, as well as the skills that children gain through ICT use. To this end, this article examines both Polish and international literature in the field of psychology and pedagogy regarding the complexity of ICT, the protection of children from the threats of ICT use, and the practical implications of ICT use for parents, teachers, and policy makers.

Key words: context of development, new technologies, childhood, ICT, opportunities, threats.

\section{Introduction}

In recent years, globalization has led to drastic changes in the modern world. Intense technological advancements, economic changes, and above all the development of new technologies have had a huge impact on the lives of modern people. These changes also pertain to 
the environment in which people live; for, they complicate the context in which people, including children and youth, develop.

\section{An Explanation of Terms}

Studies use different terms to describe new technologies, including information and communications technology (ICT), teleinformatics, or simply information technology (IT). Numerous theoretical and research studies conducted by psychologists, pedagogues, sociologists, and media experts have analyzed IT or digital competences. ${ }^{1}$ These competences involve proper (beneficial) internet use and are essential for further learning in the modern schools. ${ }^{2}$

The term "context" is often synonymous with the word "environment" and refers to an individual's external situation. H. R. Schaffer defines "context" more broadly as "the multilayered environment of an individual who behaves according to how he perceives it." 3 Schaffer continues by breaking down the meaning of this definition: by "multilayered" he means that an individual functions in a set system of contexts that are made up of physical, interpersonal, cultural, and historical environments. The American psychologist and author of the ecological ${ }^{4}$ and later bioecological ${ }^{5}$ models of human development, Urie Bronfenbrenner, studied the context in which a person develops. According to Bronfenbrenner's theory, the context of human development involves five related systems. The microsystem is any environment (i.e., family home, school, peer group, church group) where the developing person spends a lot of time engaging in activities and interacting. If people spend time in more than one microsystem, then the interactions between these microsystems comprise the mesosystem. The exosystem is also an important context in which a person does not

1 P. Siuda, Kompetencje informatyczne a informacyjne-uczniowie i nauczyciele, 2015, https://www.researchgate.net/publication (09.29.2017).

2 European Parliament and Council,Zalecenie wsprawie kompetencjikluczowych $w$ procesie uczenia się przez całe życie (Recommendation on Key Competences in Life Long Learning), December 18, 2006 (2006/962/WE), 2, http://eurex.europa. eu (09.28.2017).

H.R. Schaffer, Psychologia rozwojowa. Podstawowe pojęcia (Cracow: Wydawnictwo Uniwersytetu Jagiellońskiego, 2010), 21. and Design (Cambridge Massachusetts and London: Harvard University Press, 1979).

$5 \quad$ U. Bronfenbrenner, Making Human Beings Human: Bioecological Perspectives on Human Development (Thousand Oaks: SAGE Publications, 2005). 
directly participate but that nevertheless impacts him (i.e., a child's parents' jobs). According to Bronfenbrenner, the macrosystem is made up of every group (i.e., culture, subculture) whose members share the same values, belief systems, lifestyle, and patterns of social change. ${ }^{6}$ While the macrosystem includes and affects the other systems, it is also influenced by them. The fifth system-the chronosystem-is comprised of the environmental and socio-historical events and changes that occur throughout a child's life.

According to Bronfenbrenner, a person's development manifests itself in: a) taking on new roles and occupying new positions in new environments, $b$ ) expanding and diversifying one's environments and enriching the relationships that one has entered into with them, and c) getting involved in activities directed towards the environment. ${ }^{7}$

Up to now, the environment has been understood as an individual's physical surroundings; this definition, however, omits other contexts and emphasizes that the environment in which one develops is dynamic, not static. For example, during the early stages of life, a child learns mainly within the context of interpersonal relationships with the adults who can continually tailor their guidance and indications based on their perception of the child's ever-changing understanding. ${ }^{8}$ This approach emphasizes the important role of the child plays in the adults' assessment and interpretation of the child's surroundings. Unlike the traditional division between the individual (that which is interior) and the environment (that which is exterior), "the external can become a part of the internal, so that the two aspects create one complete system." 9

Super and Harkness conceptualize context in terms of a developmental niche, which is understood as "the child's place in a particular community, which is subsequently determined by many cultural factors that dominate within the community and influence the child's development." ${ }^{10}$ Bronfenbrenner's concept of human development is based on the reciprocal interactions between individuals and the environment. According to Bronfenbrenner, a developing person does not

$6 \quad$ U. Bronfenbrenner, and S.J. Ceci, Nature-Nurture Reconceptualized in Developmental Perspective: A Bioecological Model 101, no. 4 (Psychological Review, 1994): 568-586.

M. Przetacznik-Gierowska and M. Tyszkowa, Psychologia rozwoju człowieka 1 (Warsaw: 1996): 95.

H. R. Schaffer, Psychologia rozwojowa, 21.

Ibid. 
passively experience stimuli from his immediate surroundings; rather, and individual is a growing and dynamic being who, when entering a new environment, changes its structures. Interactions between an individual and the environment are bi-directional and, therefore, defined as reciprocal.

Recently, the traditional concept of the context of human development has changed due to the intensive development of ICTs and the widespread access that young children have to them. New technologies have transformed contemporary media and its role not only in the lives of adults but also of children; for, these technologies have become both a part of the social and educational context that also contributes to the socialization of the young today. As a result of the theory of technological determinism, ${ }^{11}$ the concept of technology and early socialization has emerged in studies..$^{12}$ So-called "mediated communication," otherwise understood as a specific kind of interpersonal communication that arises in new media (particularly in social media), has become a widespread and increasingly important medium of socialization. ${ }^{13}$

Today, the family is still the primary and most important environment for socialization. However, the role and position of electronic media and new technologies within this context are changing. According to Jadwiga Izdebska, "modern children are quickly coming out from under the influences of their closest environments: family, school, the church. Now electronic media: television, computers, the Internet, and mobile phones are the primary means of their socialization." ${ }^{14}$ Today, it is possible to include smartphones and tablets to Izdebska's list of media that is widely available to children. The advantage of this media is its mobility, which makes it possible to use these devises virtually anywhere, in every situation, and without limit.

$11 \quad$ M. Klichowski, "Czy nadchodzi śmierć tekstu? Kilka refleksji na marginesie teorii technologicznego determinizmu," Studia Edukacyjne, no. 23 (2012).

12 J. Pyżalski and M. Klichowski, Technologie informacyjno-komunikacyjne a dzieci $w$ wieku przedszkolnym-model szans i zagrożeń, https://repozytorium. amu.edu.pl.

13 Ibid, 2.

14 J.Izdebska,Dzieckowświecie mediówelektronicznych. Teoria, badania, edukacja medialna (Bialystok: Wydawnictwo Uniwersyteckie Trans Humana, 2007), 73. 


\section{The Role of New Technologies as the Context of Child Development}

Recent studies show that in many countries most young children (up to 5 years of age), even those from families of low economic status, use the latest mobile digital technologies (smartphones, tablets) ${ }^{15}$ while $75 \%$ of children in Europe use internet resources. Parents who use technological devices such as smartphones or tablets to navigate the Internet are fascinated by new technologies and are eager to share them with their children. Easy internet access presents many advantages; for example, older children can use new technologies to obtain information, and both other and younger children can use them for recreation (games, videos, educational programs).

Younger children's use of ICT is controversial, especially among physicians, psychologists, and pedagogists. Up to now, in-depth scientific analysis of the impact of new technologies on child development in different areas is still lacking. It is worthwhile to analyze the impact of digital media on the health and development of children, especially children under the age of 5 years, because this is considered a unique and critical period of human and brain development when a child learns to build secure relationships with others, how to behave properly, and establish healthy habits. Some researchers view ICT as a threat to child development and learning, and they point to the increasing incidence of physical problems such poor posture, sight problems, obesity (due to insufficient physical activity in children), or carpal tunnel syndrome. ${ }^{16}$ They observe that technology use makes learning through direct experience of the world, which is particularly important for very small children, obsolete. It also leads to social isolation, difficulty concentrating, language impairment, ${ }^{17}$ or educational problems (i.e., imitation of socially undesirable and violent behaviors seen in some computer games).

15 L. Kirwil and A. Zdrodowska, "Korzystanie z internetu i bezpieczeństwo dzieci w sieci: Polska a Europa w raportach z badań EU Kids Online," Studia Medioznawcze 42, no. 3 (2010): 133-136.

16 I. Siraj-Blatchford, J. Siraj-Blatchford, More than Computers: Information and Communication Technology in the Early Years (London: The British Association for Early Childhood Education, 2003).

17 C. Cordes and E. Miller. Fool's Gold: A Critical Look at Computers in Childhood (New York: Alliance for Childhood Publications, 2000); J. M. Healy, "Cybertots: Technology and the Preschool Child," in All Work and No Play: How Educational Reforms are Harming Our Preschoolers," ed. S. Olfman (Westport: Praeger, 2003), 83-111. 
The American Academy of Pediatrics recommends that infants and toddlers up to 2 years of age should not be exposed to mobile devices at all, ${ }^{18}$ since they need to engage in direct motor exploration of their environment and social interaction with a caregiver in order to properly develop cognitive, linguistic, motor and socio-emotional skills. The best way to improve a child's immature symbolic memory, or attention span, is by enabling a child to have direct contact with other people. Digital media does not provide opportunities such as direct social relationships, and young children have difficulty transferring the knowledge they acquire through flat-screen digital media to the three-dimensional reality in which they live. ${ }^{19}$

Meanwhile, a survey conducted by the Fundacja Dzieci Nieczyje (Empowering Children Foundation) in Poland in 2015 shows that $64 \%$ of children aged 6 months to 6.5 years use mobile devices. ${ }^{20}$ Of these children, $25 \%$ use these devices daily, $26 \%$ have their own mobile device, $79 \%$ watch movies, $62 \%$ play on smartphones or tablets, and $63 \%$ play with a smartphone or tablet without a specific purpose. Furthermore, $69 \%$ of parents give their children mobile devices to distract them when parents need to do something, and $49 \%$ use mobile devices as a reward for their children, $19 \%$ use them as a means of getting their children to eat, and $15 \%$ of parents use them as a bribe to get their children to go to sleep. It is alarming that almost one third of children are in contact with mobile devices each year, and this is a common phenomenon among children 5 to 6 years of age. Research also shows that, insofar as parents are increasingly limiting the amount of time their 1-year-old children can use mobile devices each year, they are equally permitting their 2-year-old children to increase their exposure to and use of technology ( $84 \%$ of the children surveyed watch mobile videos on the internet each day, while $34 \%$ of 2 -year-olds were permitted by their parents to watch videos during meals).

Needless to say, mobile devices make it easier for children to navigate the Internet. On the one hand, internet access makes it possible for young children to gain knowledge and make contact with other

18 American Academy of Pediatrics, "Policy Statement: Media Use by Children Younger Than 2 Years," Pediatrics 128, no. 5 (AAP Publications, 2011): 1040-1045.

19 American Academy of Pediatrics Council On Communications And Media, "Policy Statement: Media and Young Minds," Pediatrics (AAP Publications, 2016): 138. This document was originally published online on October 21, 2016.

$20 \quad$ Bąk A. Raport z badania: Korzystanie z urzadzeń mobilnych przez małe dzieci $w$ Polsce. Wyniki badania ilościowego, (Warsaw: Wydawnictwo Fundacja Dzieci Niczyje, 2015). 
people. On the other hand, however, it also increases their risk for exposure to threats and dangers.

Literature shows that the there are a variety threats to children involving internet use: ${ }^{21}$

- peer pressure (i.e., "all my friends have a smart phone, are using this chat forum, etc."),

- lack of parental control over how children spend their free time,

- complete absence of or poorly formed affective relationships among family members, and

- isolation of children (i.e., children are not given or are only rarely entrusted with domestic obligations).

Additionally, Parry Aftab specifies six types of threats that children may encounter on the Internet: ${ }^{22}$

1. They can find information that is inappropriate for them: pornography, hate speech, intolerance, bigotry, fraud, and untruthful and exaggerated information.

2. They can access a plethora of information and services, and they can purchase dangerous items. For example, there are internet sites that teach people how to make bombs, offer gambling, and sell weapons, alcohol, poisons, tobacco, and narcotics.

3. They can be harassed by people (often other children) who are vulgar, offensive, threatening, and able to hack into and infect their computers with viruses.

4. They can provide other people (strangers) with confidential information by filling out forms, participating in contests, signingup for services and, therefore, becoming targets for scammers, swindlers, and market fraudsters.

5. They can be deceived and taken advantage of when they buy something online. In the process, they risk disclosing relevant financial information such as credit card numbers, PINs, and passwords.

6. They can be seduced by cyber strangers who seek to meet (and abuse) them in person.

Jolanta Biała also describes the negative effects of uncontrolled internet use on various spheres of human development: ${ }^{23}$

$21 \quad$ A. Filipek, "Dziecko w kontekście zagrożeń Internetu," in Wielowymiarowość przestrzeni życia wspótczesnego dziecka, eds. J. Izdebska and J. Szymanowska (Bialystok: Wydawnictwo Trans Humana, 2009), 381.

22 P. Aftab, Internet a dzieci. Uzależnienia i inne niebezpieczeństwa (Warsaw: Wydawnictwo Prószyński i S-ka, 2003), 84.

${ }^{23} \quad$ J. Biała, Zagrożenia $w$ wychowaniu dziecka we współczesnej rodzinie polskiej (Kielce: Wydawnictwo Akademii Świętokrzyskiej, 2006), 105. 
1. Physical threats: eyestrain, back strain (resulting in poor posture maintained over a long period of time), headaches, wrist pain, and fatigue.

2. Psychological threats: internet addiction to such a degree that a person feels certain and safe only when in front of the computer. As a result, he become more distant from his loved ones.

3. Moral threats: internet sites that encourage premature sexual activity such as intercourse, sexual acts, and masturbation, and provide easy access to pornography.

4. Social threats: anonymity on the Internet makes it possible for people use vulgarities or employ psychotechnology which threatens proper social communication.

5. Intellectual threats: a child's close proximity to internet content compromises the child's ability to think critically and creatively; children often believe that the information provided on the internet is true.

From 2006 to 2009, the following 21 European countries participated in the EU Kids Online survey "Safer Internet Plus:" Austria, Belgium, Cyprus, Czech Republic, Denmark, Estonia, France, Greece, Spain, Holland, Iceland, Ireland, Germany, Norway, Poland, Portugal, Slovenia, Sweden, Great Britain, and Italy. ${ }^{24}$ The aim of this survey was to compare current research on internet use by children. Since then, these surveys have been repeated every few years and revealed that the main threats to children are: exposure to inappropriate content, contact with other people (strangers) on the Internet, and internet use. So far, studies have analyzed the opportunities and risks that the Internet poses to older children, but they have not analyzed the online risks to young children. Studies have analyzed the opportunities and risks that internet use poses to young children, and they have found that the opportunities pertain to the following areas:

1. Obtaining knowledge, education, and technological skills: educational resources, contact with other people who share similar interests, self-initiated and collaborative learning;

2. Civic participation and involvement: global information, exchanges among interest groups, concrete forms of civic involvement;

$24 \quad$ L. Kirwil and A. Zdrodowska, "Korzystanie z internetu i bezpieczeństwo dzieci w sieci: Polska a Europa w raportach z badań EU Kids Online," Studia Medioznawcze 42, no. 3 (2010): 133-136. 
3. Creativity and self-expression: diverse resources, invitations and inspiration to be creative or participate in creative endeavors, user-generated content; and

4. Identity and social relationships: advice pertaining to health and personal life, social relationships, shared experiences, and self-expression.

Literature lists the following as the most frequently mentioned dangers associated with children's use of the online resources:

1. Commercial subjects, content, and activities: advertisements, spam, sponsorships; tracking and collection of personal information; contamination, illegal downloads, hacking;

2. Aggression: violent and macabre content, hate, intimidation, harassment, persecution, as well as the intimidating and harassing others;

3. Pornography and harmful sexual content: sexually harmful pornographic content, meeting strangers, preparing for sexual encounters, creating and posting pornographic content; and

4. Undermining value systems: racist content, subjective information and advice (e.g., pertaining to drugs), self-harm, unwanted persuasion, giving advice (e.g., pertaining to suicide or promoting anorexia).

Despite the many threats cited in studies, technology continues to be promoted in early childhood education as a teaching tool. Research has also increasingly confirmed technology's positive impact on child development and education. With this in mind, the education system in Poland is responding to the need to develop skills to navigate the world of new technologies. The 2017 basic curriculum for general education lists one of the skills that students should develop in primary school as "creative problem solving in a variety of areas while consciously using computer science-based methods and tools, including programming. [...] Schools should make it possible for students to acquire the knowledge and skills necessary to problem solve using the methods and techniques derived from IT, including logical and algorithmic thinking, programming, computer applications, and information from various sources. To this end, students should use computers and basic digital devices and apply the skills they have learned in class to a variety of subjects, including, for example, typing a paper, performing calculations, processing information, and presenting the information in various forms and ways." ${ }^{25}$ In grades I-III of primary school, one of the

25 The Ordinance of the Ministry of National Education issued in Poland on February 14,2017 , on the core curriculum for pre-primary education and the core 
basic tasks is "to provide access to sources of information and modern technology that are valuable in the context of student development." ${ }^{26}$

Because of the prevalence of early childhood access to new technologies, psychological and pedagogical literature emphasizes that preschool children need to develop digital literacy. ${ }^{27}$ In recent years, the term "digital childhood" has appeared in scientific literature ${ }^{28}$ thereby pointing to the increasing importance of digital technology in childhood. In fact, digital technologies have already become an important part of preschool activity. The number of kindergarten children and teachers who have daily access to tablets or interactive whiteboards is steadily increasing. ${ }^{29}$ Teachers who work with young children should also develop and update their competence in digital technologies. Research shows that preschool teachers less often perceive the use of modern technology by children as a threat to their development and more often see the possibilities of using ICT in the education of young children. ${ }^{30}$ More often people point out that ICTs

curriculum for general education for primary schools, including for students with modest or even severe intellectual disabilities; general education for the first-cycle education sector; general education for adoption by special schools; and general education for post-secondary schools. Ordinance Number 356. http:// prawo.sejm.gov.pl/isap.nsf/DocDetails.xsp?id=WDU20170000356

Ibid.

L. Arnot of the University of Strathclyde, United Kingdom, and E. Karagiannidou of Victoria University, Australia, presented "The early years technological landscape," at the 27th EECERA Conference: "Social Justice, Solidarity, and Children's Rights," which took place in Bologna, Italy from August 29-September $1,2017$.

In 2014, a group of researchers from across the world within the Early Childhood Education Research Association (EECERA) founded a SIG (Special Interest Group) to research Digital Childhoods in 2014. Specifically, the aim of their studies is to analyze children's use of modern technologies in education and recreation, as well as the effect of ICTs on the development of children in different areas.

J. Snöberg, A. Lagergren, and K. Holmberg of Halmsted University, Sweden, prepared and delivered the speech Seen but not heard?! Children's participation in research about digital technology in preschool and at the 27th EECERA Conference: "Social Justice, Solidarity, and Children's Rights," which took place in Bologna, Italy from August 29-September 1, 2017.

S. Kerckaert, R. Vanderlinde, and J. van Braak, "The role of ICT in early childhood education: Scale development and research on ICT use and influencing factors," European Early Childhood Education Research Journal 23, no. 2 (Routlege: 2015). 
are not threatening; rather, the threat lies in how they are being used (for good or for bad). ${ }^{31}$

According to M. Hatzigianni and K. Margetts, ICT creates a new space for exploration and discovery, offering new challenges and satisfying children's curiosity. ${ }^{32}$ There is the potential to use new information and communication technologies, including games, applications, programs, websites, portals, etc., in the child development process in the case of preschool children ages 3 to 6 years. In this sense, Michał Klichowski et al. emphasize the advantages of new technologies that can serve as excellent and valuable tools for a child who is learning. ${ }^{33}$ Klichowski et al. cite the many psychologists and pedagogists who indicate that ICTs have many advantages in the context of child development when used by responsible parents in a well thought out manner. ${ }^{34}$ Here are some examples:

1. Children, especially preschoolers, are more likely to play with ICT than traditional toys, so their cognitive activity when using ICT is much more effective, meaning it has quicker and lasting results.

2. ICT provides children with an unprecedented amount of information, which is an essential environment that stimulates a child's cognitive development. ICT also gives children the opportunity to construct knowledge based on content that is not available in situations where media is inaccessible and, therefore, creates a completely new context for cognitive stimulation.

3. In stimulating a child's learning process, ICT makes it possible for the child to experience something that would normally be difficult to experience (i.e., in situations without ICT) or even impossible to experience (e.g., looking at the Earth's magnetic poles).

4. By helping a child to develop a variety of skills, ICT stimulates the child particularly within the context of developing its ability to learn and, therefore, its capacity in the scope of meta learning. In this way, ICT becomes a tool for lifelong learning as well as a context for cogitating methods of learning.

31 J. Pyżalski, M. Klichowski, Technologie informacyjno-komunikacyjne.

32 M. Hatzigianni and K. Margetts, “'I Am Very Good at Computers:' Young Children's Computer Use and Their Computer Self-Esteem," European Early Childhood Education Research Journal 20, no. 1 (2012): 3-20.

33 M. Klichowski, J. Pyżalski, K. Kuszak, and A. Klichowska, "Jak technologie informacyjno-komunikacyjne mogą wspierać rozwój dziecka w wieku przedszkolnym?-studium teoretyczne," in Małe dzieci w świecie technologii informacyjno-komunikacyjnych - pomiędzy utopijnymi szansami a przesadzonymi zagrożeniami, ed. J. Pyżalski (Lodz: Wydawnictwo “Eter,” 2017), 115-157.

Ibid, 118. 
Michał Klichowski et al. also refer to studies that show that children's use of new technologies during the course of their play and learning stimulates speech development and language competencies such as vocabulary enhancement, the use of longer sentence structures, and writing skills (e.g., typing on a smartphone or tablet using a simple graphical interface).$^{35}$ One advantage of ICT is that it makes it possible for a child to work individually and at its own pace, and independently document its own achievements, both of which subsequently motivate learning.

The Modern Poland Foundation's 2012 Cyfrowa Przyszłośc: Katalog kompetencji medialnych $i$ informacyjnych (The Digital Future: A Catalog of Media and Information Competences) report described the media and information competences of preschoolers. Based on the report, Michat Klichowski, Jacek Pyżalski, Kinga Kuszak, and Anna Klichowska have developed proposal to prepare ICTs for preschoolers (ages 3-6 years). ${ }^{36}$ In their opinion, if properly designed and selected, ICTs can support child development in every area:

1. They should mobilize a child to seek out and learn (from) a variety of informational sources that are age-appropriate in terms of both content and complexity.

2. They should show the possibility of so-called "intellectual prosthetics" (profit from the knowledge of others, especially important adults) and mobilize a child to collaborate when seeking information.

3. They should encourage a child to verify the information that it is receiving and even suggest that the information that the child has found may be incorrect.

4. They should incline a child to interpret the content and make comparisons based on the knowledge that the child has already gained from its own experiences.

5. They should enable a child to become familiar with various forms of media and to select them.

6. They should be simple and intuitive to use.

7. They should enable a child to become familiar with various forms of communication and give a child the opportunity to understand the differences between direct communication and ICT, between reality and the world of media.

\footnotetext{
$35 \quad$ M. Klichowski, J. Pyżalski, K. Kuszak, and A. Klichowska, "Jak technologie informacyjno-komunikacyjne," 148. 
8. They should present a child with different types of media and teach them child how to navigate them.

9. They should stimulate a child to explore the various functions of ICT.

10. They should give a child the possibility to create and choose elements of ICT (e.g., the color of background applications, the shape of the icons, etc.).

11. They should give the child the opportunity to choose the form of activity, especially in terms of communication.

12. They should give the child the possibility to stop the activity at any time and paraphrase the lesson to an adult.

13. They should be activated in such a way that a child can independently achieve the designated goal and communicate the goal to other persons (but only in the case when the goals can be easily achieved).

14. They should enable a child to do or make something of his own creation and then present what he has done (or see what other people-peers, relatives-have done).

15. They should help children be sensitive to the needs of those who are less abled, and they should be adapted for children who have special educational needs.

16. They should allow a child to transmit to and share with others (e.g., his peers) the information that he has acquired.

Anna Basinska ${ }^{37}$ emphasizes that adults are expected to create an external context for children's activities in the following different ways:

1. By creating an optimal space for children to work;

2. By supporting children's activities and stimulating the areas that they choose (e.g., by providing the necessary information, hints, tools, and also by reducing tension and providing emotional support); and

3. By changing children's behavior so that they are able to follow new rules. This is achieved by encouraging children to try new activities and placing them in problematic situations.

Whether or not children properly use ICTs depends on the adultsparents and teachers-entrusted with their care.

$37 \quad$ A. Basińska, Odkrywanieświata. Oaktywności poznawczejdziecka w przestrzeni edukacyjnej środowiska, (Poznan: Wydawnictwo Naukowe UAM, 2012). 


\section{Conclusion}

Not only research is interested in children's use of new technologies, but also parents and teachers, who often base their discussions on this topic on current opinions that have yet to be verified by research.

As ICT presents new ways to support child development, it also poses certain dangers, particularly when its use is inappropriate or uncontrolled. For this reason, it is not only essential to continually increase parents and teachers' awareness of children's positive and negative experience with ICT, but also of the synergistic relationship between all environments, meaning the integration and cooperation of many communities: family, school, peer groups, local communities, media, and other the areas, that are involved in the education, socialization, and inculturation of children. The new contexts of child development and education that are arising due to ever-changing technologies make it necessary for various environments to collaborate in order to bring their educational and upbringing influences together, even in those areas not yet known to adults. All adults involved in this process should act in a similar way and according to the same principles, goals, and values.

\section{NOWOCZESNE TECHNOLOGIE JAKO NOWY KONTEKST ROZWOJU DZIECKA - MOŻLIWOŚCI I ZAGROŻENIA}

Powszechne używanie przez małe dzieci nowych technologii informacyjno-komunikacyjnych wywołuje kontrowersje w wielu krajach. Niezwykle istotne wydaje się zrozumienie wpływu nowych urządzeń cyfrowych, takich jak np. tablety na rozwój dziecka. Celem rozważań jest analiza zjawiska nowych technologii (TIK) jako kontekstu rozwoju, uczenia się i socjalizacji małego dziecka. W artykule skoncentrowano się na technologiach używanych we wczesnej edukacji: jak są definiowane, w jaki sposób wpływają na dzieciństwo (możliwości i zagrożenia), jaka jest rola i potencjał TIK we wczesnej edukacji, jakie nowe kompetencje zdobywają dzieci w kontakcie zTIK. Artykuł jest przeglądem polskiej i zagranicznej literatury psychologicznej i pedagogicznej, wskazano w nim na kompleksowość roli TIK i ochrony dzieci przed zagrożeniami, zawiera także implikacje praktyczne dla rodziców, nauczycieli i decydentów.

Słowa kluczowe: kontekst rozwoju, nowe technologie, dzieciństwo, technologie informacyjno-komunikacyjne: możliwości i zagrożenia. 


\section{Bibliography:}

1. American Academy of Pediatrics Council On Communications And Media, "Policy Statement: Media and Young Minds," Pediatrics (AAP Publications, 2016): 138.

2. American Academy of Pediatrics, "Policy Statement: Media Use by Children Younger Than 2 Years," Pediatrics 128, no. 5 (AAP Publications, 2011): 1040-1045.

3. Arnot, L. and E. Karagiannidou. "Social justice, solidarity and children's rights." Talk delivered at the 27th EECERA Conference: The early years technological landscape, Bologna, Italy, August 29-September 1, 2017.

4. Basińska, A. Odkrywanie świata. O aktywności poznawczej dziecka $w$ Miscellanea przestrzeni edukacyjnej środowiska. Poznan: Wydawnictwo Naukowe UAM, 2012.

5. Bąk, A. Raport $z$ badania: Korzystanie $z$ urządzeń mobilnych przez mate dzieci w Polsce. Wyniki badania ilościowego. Warsaw: Fundacja Dzieci Niczyje, 2015.

6. Biała, J. Zagrożenia w wychowaniu dziecka we wspótczesnej rodzinie polskiej. Kielce: Wydawnictwo Akademii Świętokrzyskiej, 2006.

7. Bronfenbrenner, U. The Ecology of Human Development: Experiments by Nature and Design. Cambridge, Massachusetts, and London: Harvard University Press, 1979.

8. Bronfenbrenner, U. Making Human Beings Human: Bioecological Perspectives on Human Development. Thousand Oaks: SAGE Publications, 2005.

9. Bronfenbrenner, U. and S. J. Ceci, Nature-Nurture Reconceptualized in Developmental Perspective: A Bioecological Model 101, no. 4 (Psychological Review, 1994): 568-586.

10. Cordes, C., and E. Miller, Fool's Gold: A Critical Look at Computers in Childhood. New York: Alliance for Childhood Publications, 2000.

11. European Parliament and Council, Zalecenie w sprawie kompetencji kluczowych w procesie uczenia się przez cate życie (Recommendation on Key Competences in Life Long Learning)," December 18, 2006 (2006/962/ WE), 2, http://eurex.europa.eu (09.28.2017).

12. Filipek, A. "Dziecko w kontekście zagrożeń Internetu." Wielowymiarowość przestrzeni życia wspótczesnego dziecka. Edited by Jadwiga Izdebska and Joanna Szymanowska. Bialystok: Trans Humana Wydawnictwo Uniwersyteckie, 2009.

13. Healy, J. M. "Cybertots: Technology and the Preschool Child." In All Work and No Play: How Educational Reforms are Harming Our Preschoolers." Edited by S. Olfman. Westport: Praeger, 2003, 83-111.

14. Hatzigianni, M. and K. Margetts. "'I Am Very Good at Computers:' Young Children's Computer Use and Their Computer Self-Esteem." European Early Childhood Education Research Journal 20, no. 1 (2012): 3-20.

15. Izdebska, J. Dziecko w świecie mediów elektronicznych. Teoria, badania, edukacja medialna. Bialystok: Wydawnictwo Uniwersyteckie Trans Humana, 2007.

16. Kerckaert, S., R. Vanderlinde, and J. van Braak, "The role of ICT in early childhood education: Scale development and research on ICT use 
and influencing factors." European Early Childhood Education Research Journal 23, no. 2 (Routlege: 2015).

17. Kirwil L., and A. Zdrodowska. "Korzystanie z internetu i bezpieczeństwo dzieci w sieci: Polska a Europa w raportach z badań EU Kids Online." Studia Medioznawcze 42, no. 3 (2010): 133-136.

18. Klichowski, M., J. Pyżalski, K. Kuszak, and A. Klichowska. "Jak technologie informacyjno-komunikacyjne mogą wspierać rozwój dziecka w wieku przedszkolnym?-studium teoretyczne." In Mate dzieci w świecie technologii informacyjno-komunikacyjnych - pomiędzy utopijnymi szansami a przesadzonymi zagrożeniami. Edited by J. Pyżalski. Lodz: Wydawnictwo "Eter," 2017, 115-157.

19. Klichowski, M. "Czy nadchodzi śmierć tekstu? Kilka refleksji na marginesie teorii technologicznego determinizmu," Studia Edukacyjne, no. 23 (2012).

20. Przetacznik-Gierowska, M., and M. Tyszkowa, Psychologia rozwoju człowieka 1 (Warsaw: 1996): 95.

21. Pyżalski, J., and M. Klichowski, Technologie informacyjno-komunikacyjne a dzieci $w$ wieku przedszkolnym-model szans i zagrożen, https://repozytorium.amu.edu.pl

22. Ministry of National Education. Ordinance. No. 365. Issued February 14,2017 . http://prawo.sejm.gov.pl/isap.nsf/DocDetails. xsp?id=WDU20170000356

23. Schaffer, H. R. Psychologia rozwojowa. Podstawowe pojęcia. Cracow: Wydawnictwo Uniwersytetu Jagiellońskiego, 2010.

24. Siraj-Blatchford I., and J. Siraj-Blatchford. More than Computers: Information and Communication Technology in the Early Years. London: The British Association for Early Childhood Education, 2003.

25. P. Siuda, Kompetencje informatyczne a informacyjne-uczniowie i nauczyciele, 2015, https://www.researchgate.net/publication (09.29.2017).

26. Snöberg, J., A. Lagergren, and K. Holmberg. "Seen but not heard?! Children's participation in research about digital technology in preschool." "Social justice, solidarity and children's rights." Talk delivered at the 27th EECERA Conference: The early years technological landscape, Bologna, Italy, August 29-September 1, 2017. 